\title{
PERANCANGAN SISTEM PENGUKURAN KINERJA PT. CENTRAL PROTEINA PRIMA TbK MELALUI PENDEKATAN HUMAN RESOURCES SCORECARD
}

\author{
Erza Ardenta Wicaksana ${ }^{1}$, Darsono $^{2}$, Joko Sutrisno ${ }^{3}$ \\ Program Studi Magister Agribisnis, Universitas Sebelas Maret \\ E-mail: erza.ardenta@gmail.com
}

\begin{abstract}
PT. Central protein Prima, Tbk. still do not have a performance measurement system that supports the role of the human resources of the company's strategy. Human Resources Scorecard is a system for measuring human resource linking people, strategy and performance to produce a superior company. Human Resources Scorecard outlines the vision, mission, strategies into action Human Resources measurable contribution. PT. Central protein Prima, Tbk. requires a measurement of performance of human resources. The concept used is the company's Human Resources Scorecard in order to improve and enhance the performance of human resources in order to achieve the vision and mission of the company. The purpose of this study was to determine the performance measurement system design, implementation and comparison of results of design performance measurement results in 2013 and 2014 according to the Human Resources Scorecard at PT. Central protein Prima, Tbk. This research method using Analytical Hierarchy Process (AHP) to determine the weight and Likert scale to determine the score of the assessment of performance measurement. The results of the measurement of the performance appraisal of human resources at PT. Central protein Prima Tbk. In 2013 obtained a score of 94.6 percent means the performance has yet to reach the target with yellow and votes in 2014 obtained a score of 101.4 percent means the performance has reached the target with green ratings.
\end{abstract}

Keywords: Performance Measurement, Human Resource Scorecard, AHP

\begin{abstract}
Abstrak : PT. Central Proteina Prima, Tbk. masih belum memiliki sistem pengukuran kinerja yang mendukung peran sumber daya manusia terhadap strategi perusahaan. Human Resources Scorecard adalah suatu sistem pengukuran sumber daya manusia yang mengaitkan manusia, strategi dan kinerja untuk menghasilkan perusahaan yang unggul. Human Resources Scorecard menjabarkan visi,misi ,strategi menjadi aksi Human Resources yang dapat diukur kontribusinya. PT. Central Proteina Prima, Tbk. memerlukan suatu pengukuran kinerja sumber daya manusia. Konsep yang digunakan perusahaan adalah Human Resources Scorecard dalam rangka untuk memperbaiki dan meningkatkan kinerja sumber daya manusia sehingga tercapai visi dan misi perusahaan. Tujuan Penelitian ini adalah untuk mengetahui rancangan sistem pengukuran kinerja, implementasi hasil perancangan dan perbandingan hasil pengukuran kinerja 2013 dan 2014 berdasarkan Human Resources Scorecard di PT. Central Proteina Prima, Tbk. Metode penelitian ini menggunakan Analytical Hierarchy Process (AHP)untuk menentukan bobot dan skala Likert untuk menentukan skor dari penilaian pengukuran kinerja. Hasil dari pengukuran penilaian kinerja sumber daya manusia di PT. Central Proteina Prima Tbk. Tahun 2013 memperoleh skor 94,6 persen berarti kinerja masih belum mencapai target dengan penilaian warna kuning dan tahun 2014 memperoleh skor 101,4 persen berarti kinerja sudah mencapai target dengan penilaian warna hijau
\end{abstract}

Kata kunci : Pengukuran Kinerja, Human Resource Scorecard, AHP 


\section{PENDAHULUAN}

Perkembangan dunia bisnis yang sangat pesat memasuki abad persaingan global, sehingga setiap perusahaan berlomba-lomba memenangkan persaingan. Faktor yang menentukan suatu bisnis mempunyai daya saing tinggi adalah aset yang tidak tampak (intangible asset), seperti sumber daya manusia. SDM adalah salah satu faktor utama dalam menentukan keberhasilan perusahaan, instansi ataupun organisasi. Oleh karena itu, diperlukan sumber daya manusia yang mempunyai kompetensi tinggi yang dapat mendukung peningkatan prestasi kinerja karyawan.

Sumber daya manusia merupakan aset yang strategi karena merupakan sumber daya dengan kapabilitas yang sulit untuk ditiru, sulit dipindahkan atau dipertukarkan, bersifat langka dan unik. Kini saatnya profesional sumber daya manusia menciptakan alat ukur baru yang bisa digunakan untuk membuktikan kontribusi sumber daya manusia pada implementasi strategi perusahaan dan mengelola sumber daya manusia sebagai aset strategis (Widjaya, 2003).

Human Resources Scorecard (HRSc) adalah suatu alat untuk mengukur dan mengelola kontribusi stratejik dari peran human resources dalam menciptakan nilai untuk mencapai strategi perusahaan. (Becker, Huselid dan Ulrich, 2009).

Menurut Masruroh (2012), pengukuran kinerja perusahaan pada periode tertentu sangat diperlukan agar prestasi perusahaan dapat diketahui. Pengukuran kinerja sumber daya manusia dengan menggunakan konsep Human Resources Scorecard dapat memperbaiki dan meningkatkan kinerja sumber daya manusia perusahaan. Konsep pengukuran ini sangat penting bagi perusahaan agar dapat secara efektif mengelola tanggung jawab yang strategik untuk menghadapi persaingan di masa mendatang sehingga tercapai visi dan misi perusahaan.

Menurut Yahya (2010), sumber daya manusia merupakan fondasi bagi penciptaan nilai. Berbagai kajian menunjukkan bahwa hingga 85 persen nilai suatu perusahaan didasarkan pada intangible asset (aset yang tidak tampak,seperti sumber daya manusia). Hal ini memunculkan dilema yang menarik dimana aset yang paling penting adalah aset yang kurang dimengerti dan jarang diukur.
Karenanya perlu diwujudkan adanya pengukuran terhadap strategi sumber daya manusia.

Menurut Aryani (2008), kualitas sumber daya manusia yang dimiliki perusahaan dapat secara langsung mempengaruhi kualitas dan kelangsungan bisnis perusahaan, sehingga perusahaan membutuhkan sistem pengukuran kinerja sumber daya manusia. Perusahaan menggunakan Human Resources Scorecard dan menetapkan sasaran strategi perusahaan yang dirumuskan ke dalam peta strategi dengan dikelompokkan dalam empat perspektif yaitu, perspektif keuangan, karyawan, proses bisnis internal, dan pertumbuhan dan pembelajaran. Penyelarasan arsitektur SDM terdiri dari fungsi SDM, sistem SDM dan perilaku karyawan terhadap sasaran strategi.

PT. Central Proteina Prima Tbk masih belum memiliki sistem pengukuran kinerja sumber daya manusia sehinggga membutuhkan sistem pengukuran kinerja sumber daya manusia seperti Human Resources Scorecard. .

Tujuan dari penelitian ini adalah untuk mengetahui rancangan sistem pengukuran kinerja, implementasi hasil perancangan dan perbandingan hasil pengukuran kinerja pada tahun 2013 dan tahun 2014 di PT. Central Proteina Prima Tbk, dengan menggunakan pendekatan Human Resources Scorecard..

\section{METODE PENELITIAN}

Metode dasar yang digunakan dalam penelitian ini adalah metode deskripsi analisis. Menurut Nasir (2011) metode ini meneliti suatu objek, kondisi, pemikiran ataupun suatu peristiwa masa sekarang berdasarkan fakta fakta, kemudian dianalisis.

Penentuan lokasi didasarkan pada pertimbangan tertentu yakni untuk melihat secara utuh gambaran strategi PT. Central Proteina Prima Tbk dalam merealisasikan visi, misi perusahaan dan hubungannya dengan indikator hasil yang akan dinilai dalam 4 perspektif yaitu: perfektif keuangan, perfektif karyawan, perfektif proses bisnis internal dan perfektif pertumbuhan dan pembelajaran.

Metode analisis data menggunakan metode kualitatif dan metode kuantitatif. Pendekatan kualitatif menggunakan metode wawancara dan dokumen perusahaan meliputi analisis, pendiskripsian visi, misi dan strategi 
PT. Central Proteina Prima, Tbk, sasaran strategi, perilaku karyawan yang mendukung strategi, perancangan peta strategi, penyelarasan arsitektur SDM dengan sasaran strategi, identifikasi pengukuran dari tujuan strategis pada keempat perspektif, penentuan target dari tujuan strategis, penentuan inisiatif strategis. Hasil wawancara distruktur dalam kerangka HR Scorecard pada setiap tahapan ,

Sedangkan pendekatan kuantitatif meliputi proses pembobotan terhadap perspektif pengukuran, sasaran strategis dan indikator hasil dengan menggunakan proses hirarki analitik dan proses pencapaian sasaran.

Metode pengumpulan data dalam penelitian ini adalah dengan menggunakan wawancara dan kuesioner berupa bentuk pertanyaan terhadap direktur dan manajer personalia. Pengumpulan data primer yaitu wawancara mengenai prosedur penempatan karyawan dan staffing reward sistem dan prosedur peningkatan produktifitas kinerja karyawan, sedangkan pengumpulan data sekunder berupa sejarah singkat, struktur organisasi, visi, misi dan startegi perusahaan yang berfungsi sebagai informasi yang dibutuhkan pada tahap pertama Human Resources Score Card yakni penjabaran Visi, Misi dan Strategi PT. Central Proteina Prima Tbk.

Pada penelitian ini metode yang digunakan adalah Analhytical Hierarchy Process (AHP). Analhytical Hierarchy Process (AHP) ditemukan dan dikembangkan oleh Thomas L. Saaty, professor matematika dari Universitas Pittsburg, Amerika Serikat, sekitar tahun 1970-an. AHP adalah sebuah pendekatan pengambilan keputusan yang didesain untuk membantu pemecahan masalah yang komplek dengan criteria yang banyak dalam berbagai area aplikasi. Metode ini merupakan pendekatan yang efektif dan praktis yang dapat mempertimbangkan keputusan yang komplek dan tidak terstruktur dan memerlukan penyelarasan antara aspek kualitatif dan kuantitatif. AHP membantu para komponenkomponen penting dari suatu masalah dalam struktur hirarki.

Tahap pertama adalah perancangan Human Resources Scorecard yaitu :
1. Mendefinisikan strategi bisnis secara jelas Pada tahap ini, dilakukan penjabaran dari visi dan misi perusahaan. Strategi bisnis perusahaan harus dapat didefinisikan secara jelas, agar sumber daya manusia yang ada mampu memahami peranan mereka dalam organisasi perusahaan ke dalam tujuan strategik untuk setiap perspektif yang ada dalam sistem pengukuran Human Resources Scorecard.

\section{Membangun sebuah kasus bisnis}

Kasus bisnis merupakan gambaran kasus yang terjadi di suatu organisasi atau perusahaan berkaitan dengan strategi bisnis yang sedang dijalankannya. Kasus bisnis perlu dibangun untuk mengetahui mengapa dan bagaimana SDM dapat mendukung pencapaian strategi perusahaan. Dalam tahap ini akan diketahui tolok ukur yang akan digunakan sebagai indikator pengukuran kinerja sumber daya manusia dari setiap tujuan-tujuan strategis bisnis. Setelah diketahui tujuan strategis yang ingin dicapai,kemudian menterjemahkan visi, misi dan strategi perusahaan ke sasaran strategi,

\section{Membuat Peta Strategi Perusahaan}

Peta strategi berisi tujuan-tujuan strategis dari setiap perspektif HR Scorecard. Penyusunan peta strategis bertujuan untuk melihat secara utuh gambaran strategi perusahaan dalam merealisasikan visi, misi perusahaan dan hubungannya dengan indikator hasil yang akan dinilai. Sasaran-sasaran strategis dirancang dalam peta strategis dengan dikelompokkan dalam empat perspektif yaitu perspektif keuangan, karyawan, proses bisnis internal dan pertumbuhan dan pembelajaran. Perspektif pengukuran diurutkan dari atas ke bawah dengan urutan perspektif finansial di posisi paling atas yang merupakan muara dari seluruh perspektif yang ada dibawahnya.

\section{Mengidentifikasi $H R$ Deliverable dalam peta strategi}

Untuk mengintegrasikan sumber daya manusia ke dalam sistem pengukuran kinerja bisnis, manajer harus mengidentifikasi masalah yang menghubungkan sumber daya manusia dengan rencana-rencana implementasi strategi organisasi atau yang disebut dengan $H R$ Deliverable. HR Deliverable adalah kontribusi penting dari sumber daya manusia untuk 
mengimplementasikan strategi perusahaan (Moeheriono,2009).

\section{Menyelaraskan Arsitektur Sumber Daya Manusia dengan Sasaran Strategi}

Arsitektur SDM terdiri dari fungsi SDM, sistem SDM dan perilaku karyawan. Fungsi SDM adalah peran yang dijalankan oleh PT. Central Proteina Prima Tbk. Sistem SDM adalah kebijakan, prosedur dan taktik PT. Central Proteina Prima Tbk. Fungsi dan sistem SDM didukung oleh perilaku karyawan, sehingga tercipta hubungan antara sistem sumber daya manusia dengan sasaran strategi.

\section{Merancang Sistem Pengukuran SDM}

Sistem pengukuran melalui pendekatan $H R$ Scorecard terdiri dari menentukan ukuran kinerja, pembobotan dan menentukan target dan inisiatif strategis.

a. Penentuan Ukuran Kinerja

Penentuan ukuran kinerja terdiri dari ukuran hasil (lag indicator) dan ukuran pemacu kinerja (lead indicator) dari masing-masing sasaran strategis. Ukuran kinerja diperlukan untuk mengukur pencapaian sasaran strategis. Penentuan skor pencapaian kinerja SDM dengan skala Likert.

b. Pembobotan

Pembobotan dilakukan dengan menggunakan metode Analhytical Hierarchy Process (AHP), untuk mengetahui bobot tingkat kepentingan masing-masing perpektif. Hasil pembobotan digunakan untuk perhitungan skor pencapaian kinerja sumber daya manusia.

c. Penentuan Target dan Inisiatif Strategis Pada tahap ini ditentukan target dan inisiatif strategis terhadap pengukuran yang telah dirancang dan dikonfirmasikan ke perusahaan.

Tahap kedua adalah implementasi Human Resources Scorecar.

Setelah Human Resources Scorecard dikembangkan dengan ukuran-ukuran strategis, hasilnya menjadi alat ukur yang sangat berguna untuk menjaga skor pengaruh SDM terhadap kinerja organisasi. Implementasi Human Resources Scorecard adalah pengukuran kinerja PT. Central Proteina Prima Tbk dengan menggunakan HR Scorecard yaitu menampilkan persen pencapaian target dan skor penilaian berdasar indikator kerja.

\section{HASIL DAN PEMBAHASAN}

1. Identifikasi Visi dan Misi dan Stategi Perusahaan.

a. Visi PT. Central Proteina Prima, Tbk adalah menjadi perusahaan akuakultur terbesar dan terdepan yang terintegrasi secara vertikal di dunia.

b. Misi PT. Central Proteina Prima, Tbk adalah untuk terus menerus meningkatkan kekuatan di bidang akuakultur dan mengutamakan efisiensi melalui sistem manajemen yang inovatif serta teknologi terkini dalam rangka memastikan keberhasilan dari para petambak serta memberikan rangkaian produk yang berkualitas.

c. strategi perusahaan dari PT.Central Proteina Prima,Tbk,

a. Meningkatkan produktivitas kinerja karyawan

b. Hasil produk yang berkualitas

c. Meningkatkan pelayanan human resources yang berkualitas.

d. Meningkatkan kesejahteraan karyawan

e. Meningkatkan kepuasan karyawan.

f. Meningkatkan komitmen karyawan

g. Penempatan karyawan (staffing) .

h. Meningkatkan standar rekruitmen

i. Sistem keuangan yang baik dan teratur.

j. Sistem penilaian kinerja karyawan yang sesuai dengan strategi

k. Meningkatkan skill karyawan dan knowledge karyawan

2. Membangun sebuah kasus bisnis untuk SDM sebagai asset strategis.

Pada langkah ini dibuat sebuah kasus bisnis yang menerangkan bahwa sumber daya manusia merupakan asset strategis, kasus bisnis perlu dibangun untuk mengetahui mengapa dan bagaimana sumber daya manusia (SDM) dapat mendukung pencapaian strategi perusahaan. 
Tahapan proses pembuatan pakan udang

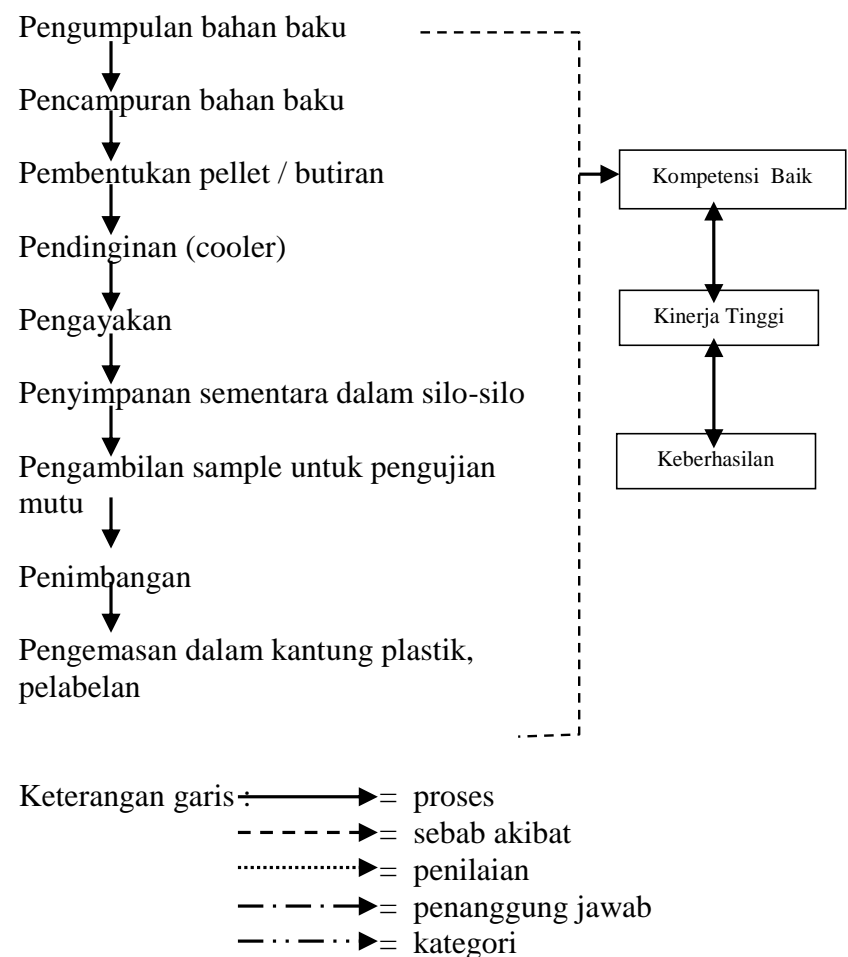

Gambar 1 Model gambaran kasus bisnis dengan SDM (Diolah oleh Penulis, 2013)

3. Membuat Peta Strategi Perusahaan dan Mengidentifikasi HR Deliverable dalam peta strategi

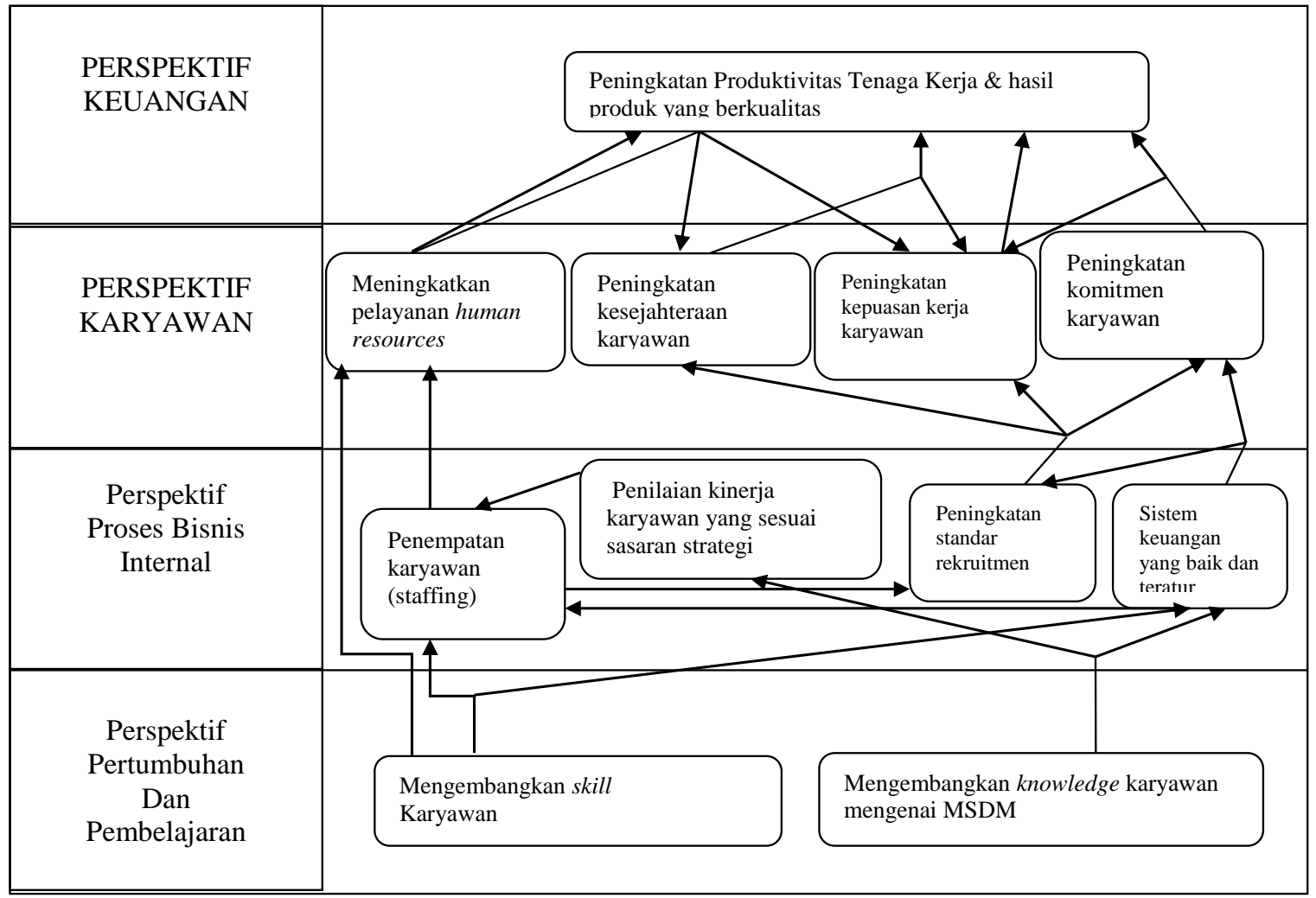

Gambar 2. Peta Strategi PT. Central Proteina Prima, TBK 
4. Menyelaraskan Arsitektur Sumber Daya Manusia Dengan Sasaran Strategis.

Brian E. Backer dan kawan-kawan menggambarkan Human, Resources Strategic Architecture (2001, hal 12) sebagai berikut :

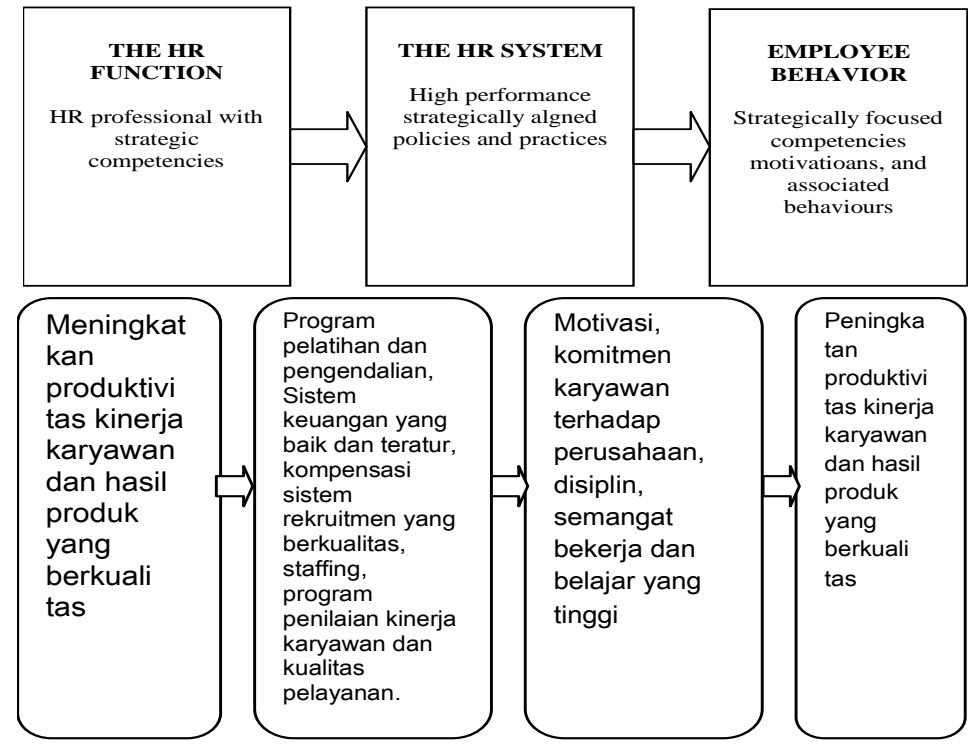

Gambar 3 Keselarasan Arsitektur SDM yang dapat mendukung peningkatan produktivitas kinerja karyawan dan hasil produk yang berkualitas

\section{Merancang Sistem Pengukuran SDM}

Tabel 1 Penentuan Prioritas pada masing-masing kriteria dan Subkriteria

\begin{tabular}{|c|c|c|c|c|c|}
\hline Perspektif & Bobot & Tujuan Strategis & $\begin{array}{l}\text { Bobot } \\
\text { Lokal }\end{array}$ & Ukuran Hasil & $\begin{array}{l}\text { Bobot } \\
\text { Global }\end{array}$ \\
\hline Keuangan & 0,483 & Peningkatan produktivitas & 1,000 & Produktivitas kinerja karyawan & 0,483 \\
\hline \multirow[t]{6}{*}{ Karyawan } & \multirow[t]{6}{*}{0,088} & \multirow{2}{*}{$\begin{array}{l}\text { Peningkatan pelayanan } H R \\
\text { berupa keselamatan dan } \\
\text { kesehatan karyawan }\end{array}$} & 0,091 & Kecelakaan kerja & 0,004 \\
\hline & & & & Jam kerja tanpa kecelakaan & 0,004 \\
\hline & & $\begin{array}{l}\text { Peningkatan kesejahteraan } \\
\text { karyawan }\end{array}$ & 0,237 & $\begin{array}{l}\text { JAMSOSTEK yang dibayarkan } \\
\text { perusahaan sesuai ketentuan }\end{array}$ & 0,029 \\
\hline & & $\begin{array}{l}\text { Peningkatan kepuasan } \\
\text { kerja karyawan }\end{array}$ & 0,141 & Indeks kepuasan kerja & 0,012 \\
\hline & & \multirow{2}{*}{$\begin{array}{l}\text { Peningkatan komitmen } \\
\text { karyawan }\end{array}$} & 0,531 & Tingkat Turnover & 0,023 \\
\hline & & & & Tingkat absensi & 0,023 \\
\hline \multirow{4}{*}{$\begin{array}{l}\text { Proses } \\
\text { Bisnis } \\
\text { Internal }\end{array}$} & \multirow[t]{4}{*}{0,272} & $\begin{array}{l}\text { Penempatan karyawan } \\
\text { (staffing) yang tepat }\end{array}$ & 0,286 & $\begin{array}{l}\text { Penempatan berdasarkan } \\
\text { permintaan penempatan karyawan }\end{array}$ & 0,078 \\
\hline & & $\begin{array}{l}\text { Peningkatan standar } \\
\text { rekruitmen karyawan }\end{array}$ & 0,182 & $\begin{array}{l}\text { Seleksi karyawan berdasarkan } \\
\text { permintaan tenaga kerja. }\end{array}$ & 0,049 \\
\hline & & $\begin{array}{l}\text { Sistem keuangan yang } \\
\text { baik dan teratur }\end{array}$ & 0,097 & $\begin{array}{l}\text { Penilaian kenaikan golongan dan } \\
\text { gaji }\end{array}$ & 0,026 \\
\hline & & $\begin{array}{l}\text { Penilaian kinerja } \\
\text { karyawan }\end{array}$ & 0,435 & Penilaian kinerja karyawan & 0,118 \\
\hline \multirow{2}{*}{$\begin{array}{l}\text { Pertumbuh } \\
\text { an dan } \\
\text { Pembelaja } \\
\text { ran }\end{array}$} & \multirow{2}{*}{0,157} & $\begin{array}{l}\text { Pengemba ngan skill } \\
\text { karyawan }\end{array}$ & 0,857 & Pelatihan skill Karyawan & 0,134 \\
\hline & & $\begin{array}{l}\text { Pengemba ngan } \\
\text { knowledge karyawan } \\
\text { mengenai MSDM }\end{array}$ & 0,143 & $\begin{array}{l}\text { Pelatihan knowledge karyawan } \\
\text { mengenai MSDM }\end{array}$ & 0,022 \\
\hline
\end{tabular}


Erza Ardenta W. , Darsono, Joko S. : Perancangan Sistem Pengukuran Kinerja ...

Tabel 2. Pengukuran Kinerja PT. Central Proteina Prima Tbk 2013 dan 2014

\begin{tabular}{lcc}
\hline \multicolumn{1}{c}{ Perspektif } & $\mathbf{2 0 1 3}$ & $\mathbf{2 0 1 4}$ \\
\hline Keuangan & 46,4 & 48,5 \\
Karyawan & 6,8 & 6,5 \\
Proses bisnis internal & 29,1 & 29,2 \\
Pertumbuhan dan pembelajaran & 12,6 & 17,2 \\
\hline Total & $\mathbf{9 4 , 9}$ & $\mathbf{1 0 1 , 4}$ \\
\hline
\end{tabular}

Sumber : PT. Central Proteina Prima Tbk.

6. Implemntasi Human Resources Scorecard. ( Lihat Lampiran )

\section{Penilaian Kinerja PT Central Proteina Prima Tbk}

Hasil Penilaian kinerja PT. Central Proteina Prima Tbk pada tahun 2013 dan 2014 dalam tiap perspektif terdapat pada tabel 1 .

Pencapaian Kinerja PT Central Proteina Prima Tbk tahun 2013 memperoleh skor total adalah 94,9 persen sehingga mendapatkan warna kuning berarti kinerja belum mencapai target. Sedangkan pencapaian kinerja tahun 2014 memperoleh skor total sebesar 101,4 persen sehingga mendapatkan warna hijau berarti kinerja telah mencapai target.

\section{KESIMPULAN DAN SARAN}

\section{Kesimpulan}

Untuk menjawab permasalahan dalam penelitian ini, maka berdasarkan hasil penelitian yang telah dianalisis dapat diambil kesimpulan sebagai berikut :

a. Pada tahap perancangan Human Resources Scorecard, perumusan sasaran strategis dan penentuan indikator hasil serta pembobotan direkapitulasi ke dalam sebuah bagan pengukuran yang menampilkan keseluruhan aspek-aspek yang diukur. Penentuan target untuk masing-masing ukuran hasil adalah merupakan salah satu langkah penting untuk merancang sistem pengukuran kinerja berdasarkan pendekatan Human Resources Scorecard. Target merupakan tingkat kinerja yang akan dicapai oleh perusahaan di masa yang akan datang.
Dalam perumusan tujuan strategi perusahaan PT. Central Proteina Prima Tbk terdapat 11 sasaran strategi dan 12 ukuran hasil yang telah dirumuskan berdasarkan perpektif keuangan, perspektif karyawan, perspektif proses bisnis internal, perspektif pertumbuhan dan pembelajaran.

b. Mengimplementasikan hasil perancangan Human Resources Scorecard, sehingga dapat diketahui pencapaian kinerja perusahaan dalam memenuhi target yang telah ditetapkan. Penilaian kinerja perusahaan menggunakan target sebagai acuan. Sistem penilaian Human Resources Scorecard menggunakan warna merah, kuning dan hijau. Hasil pengukuran Human Resources Scorecard terhadap empat perspektif, yaitu untuk perspektif keuangan mengalami kenaikkan yang cukup signifikan pada tahun 2013 ke tahun 2014 dari 46,4 penilaian warna kuning ke 48,5 penilaian warna hijau. Pada perspektif karyawan pada tahun 2013 dan 2014 dari 6,8 ke 6,5 berarti sama memperoleh penilaian warna kuning. Perspektif proses bisnis internal ada kenaikkan dari tahun 2013 ke tahun 2014 dari 29,1 ke 29,2 sama memperoleh penilaian warna hijau. Perspektif proses pembelajaran dan pertumbuhan ada kenaikkan dari tahun 2013 ke tahun 2014 yaitu dari 12,6 penilaian warna kuning ke 17,2 berarti memperoleh kategori penilaian warna hijau.

c. Perbandingan hasil pengukuran kinerja berdasarkan Human Resources Scorecard tahun 2013 dan 2014 menunjukkan hasil pengukuran kinerja keseluruhan untuk 
tahun 2013 memperoleh skor 94,9\%, berarti kinerja masih belum mencapai target dengan penilaian warna kuning. Untuk hasil pengukuran kinerja tahun 2013 pada masing-masing ukuran hasil terdapat 7 ukuran hasil yang termasuk memperoleh kategori penilaian hijau, 2 ukuran hasil yang termasuk kategori penilaian kuning dan kategori penilaian merah sebanyak 4 ukuran hasil. Sedangkan hasil pengukuran kinerja keseluruhan untuk tahun 2014 menunjukkan adanya peningkatan pencapaian kinerja yaitu, memperoleh skor 101, 4 persen berarti kinerja telah mencapai target dengan penilaian warna hijau. Untuk hasil pengukuran kinerja tahun 2014 pada masing-masing ukuran hasil terdapat 10 ukuran hasil yang termasuk kategori penilaian hijau dan 1 ukuran hasil yang termasuk kategori penilaian kuning dan kategori penilaian merah sebanyak 1 ukuran hasil.

\section{Saran}

Berdasarkan hasil kesimpulan diatas ini, maka penulis memberi saran-saran sebagai berikut :

1. Dengan adanya hasil pengukuran kinerja yang memperoleh warna merah berarti kinerja masih jauh dibawah target dan memperoleh warna kuning berarti kinerja belum mencapai target, maka perusahaan perlu melakukan upaya perbaikkan agar tercapai kinerja karyawan yang lebih baik lagi.

2. Perusahaan perlu melakukan perbaikan untuk ukuran hasil yang memperoleh warna merah berarti kinerja masih jauh dibawah target dengan cara menanamkan dalam diri karyawan suatu keyakinan bahwa mereka adalah pihak yang paling menentukan dalam pencegahan kecelakaan sehingga diharapkan dapat meminimalkan jumlah kecelakaan kerja.

3. Perusahaan perlu meningkatkan pelaksanaan pelatihan dan pengembangan sesuai dengan analisis tentang kebutuhan (training need analysis). Pengembangan SDM jangka panjang banyak memiliki manfaat dalam rangka mengurangi ketergantungan pada penerimaan karyawan baru, memberikan kesempatan kepada karyawan lama, mengantisipasi keusangan karyawan dan mengurangi perputaran tenaga kerja (turnover).

4. Perlu perbaikan untuk seleksi karyawan meskipun ukuran hasil ini telah memenuhi target dengan harapan dapat meningkatkan standar rekruitmen karyawan. Proporsi sumber rekruitmen yang baik dapat menghasilkan karyawan baru yang kompeten, oleh karena itu sebaiknya mengadakan open recruitment bekerjasama dengan kampus dan informasi lowongan kerja diusahakan bisa tersebar lebih luas dengan melakukan penyebaran informasi melalui media cetak, media elektronik atau website PT. Central Proteina Prima Tbk.

5. Perlu mengadakan program karyawan berprestasi untuk memberikan umpan balik atas upaya kerja karyawan dengan tujuan supaya dapat memacu karyawan dalam meningkatkan kinerja dan prestasi di PT. Central Proteina Prima Tbk.

\section{DAFTAR PUSTAKA}

Aryani, N, N. 2008. Perancangan Sistem Pengukuran Kinerja Departemen Personalia Melalui Pendekatan Human Resources Scorecard Pada PT. Unitex. Jurnal Teknologi Pertanian .Institut Pertanian Bogor. Bogor.

Becker, 2001. The HR Scorecard : Linking People, Strategy, and Performance. Harvard Business School Press, Massachusetts.

Masruroh, N. 2012. Pengukuran Kinerja Menggunakan Human Resources Scorecard dalam rangka Meningkatkan Kinerja di PT. Rajawali Tanjungsari. Jurnal Teknologi Industri. UPN Veteran Jatim. Surabaya

Moeheriono, 2009. Pengukuran Kinerja Berbasis Kompetensi. Ghalia Indonesia. Bogor.

Nazir, M. 2005. Metode Penelitian. Ghalia Indonesia, Jakarta

Widjaja, N. H. S. 2003. Perspektif Terbaru Manajemen Karir. Manajemen, Jakarta. 
Yahya, I. Z. 2010. Keterkaitan Kinerja Dan Kompetensi Berdasarkan Human Resources Scorecard Dengan Keberhasilan Implementasi HACCP
Pada Proses Pengolahan Tuna Loin Beku (Studi Kasus). Jurnal Teknologi Perikanan. Institut Pertanian Bogor. Bogor 


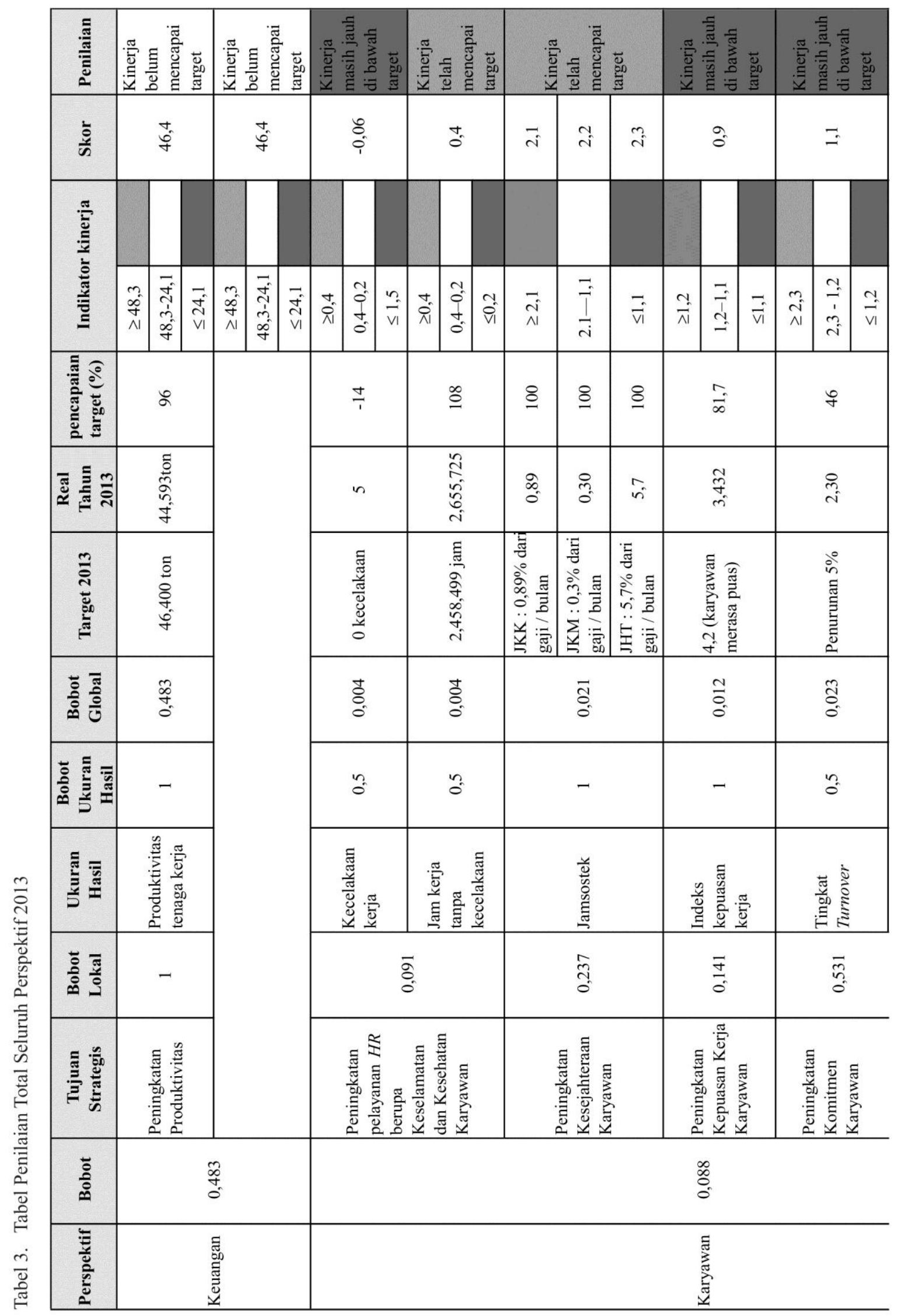


Erza Ardenta W. , Darsono, Joko S. : Perancangan Sistem Pengukuran Kinerja ...

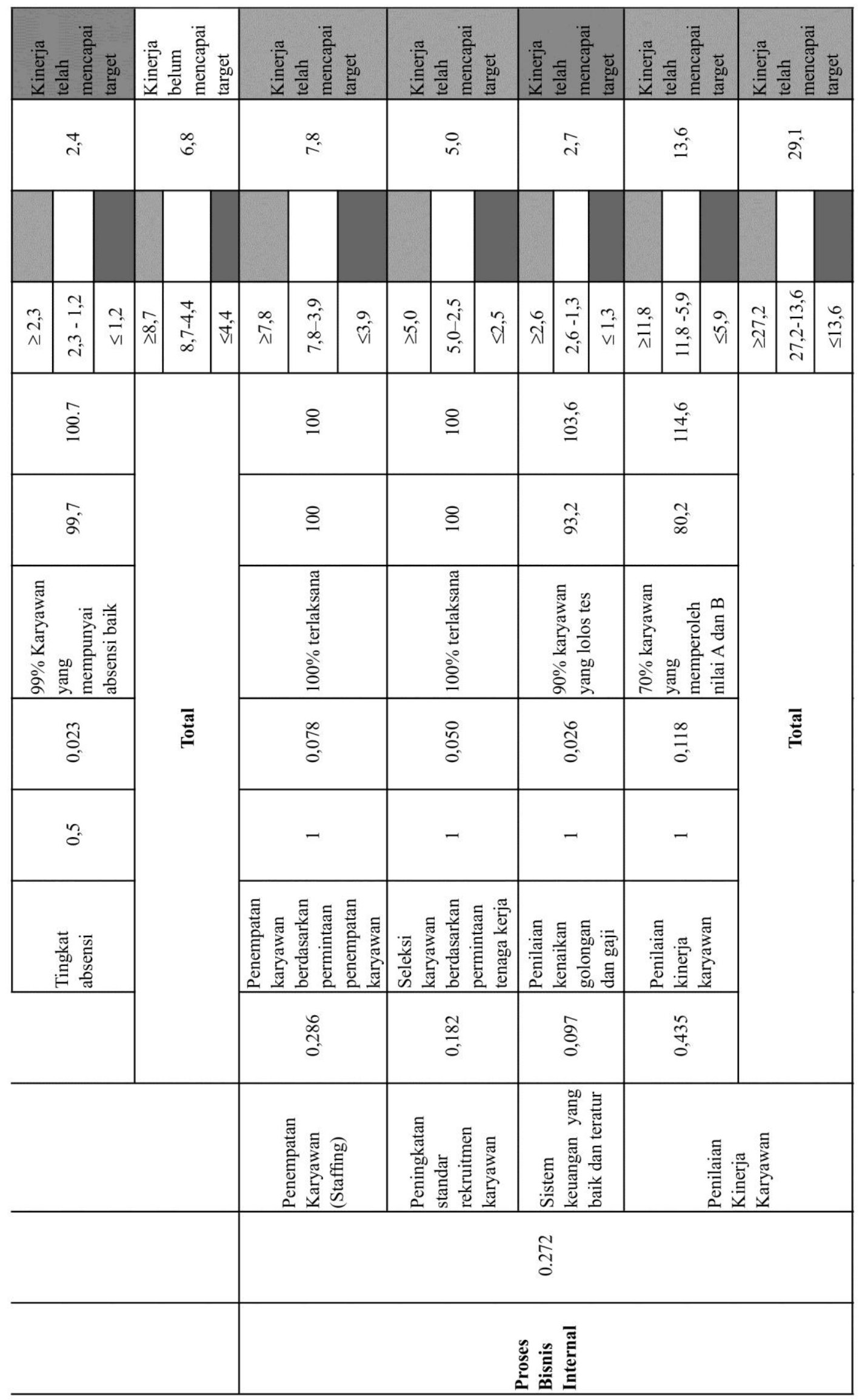


Erza Ardenta W. , Darsono, Joko S. : Perancangan Sistem Pengukuran Kinerja ...

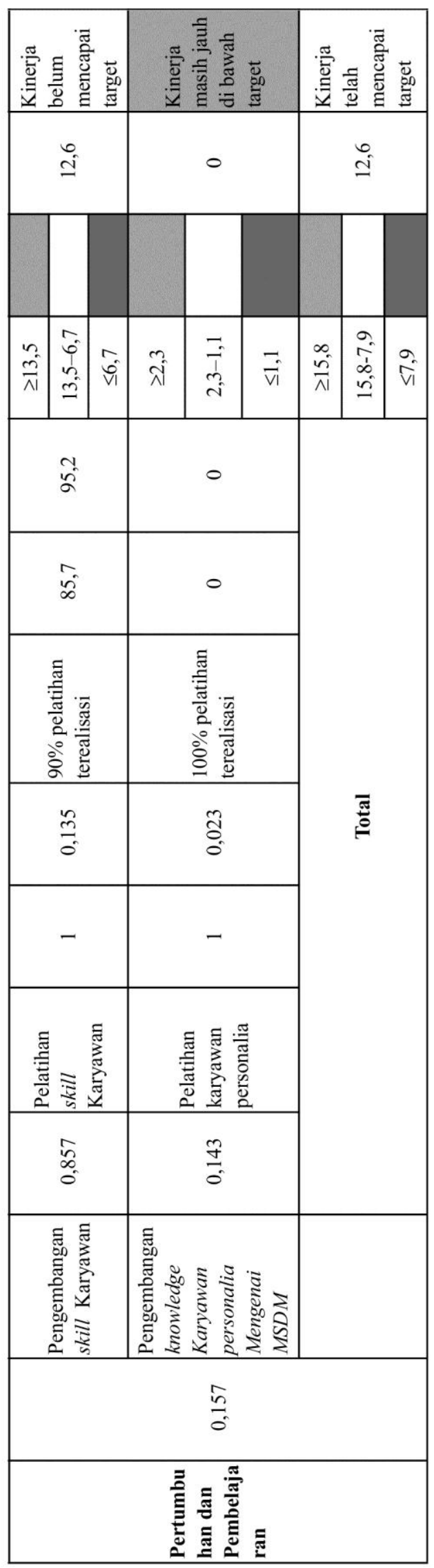

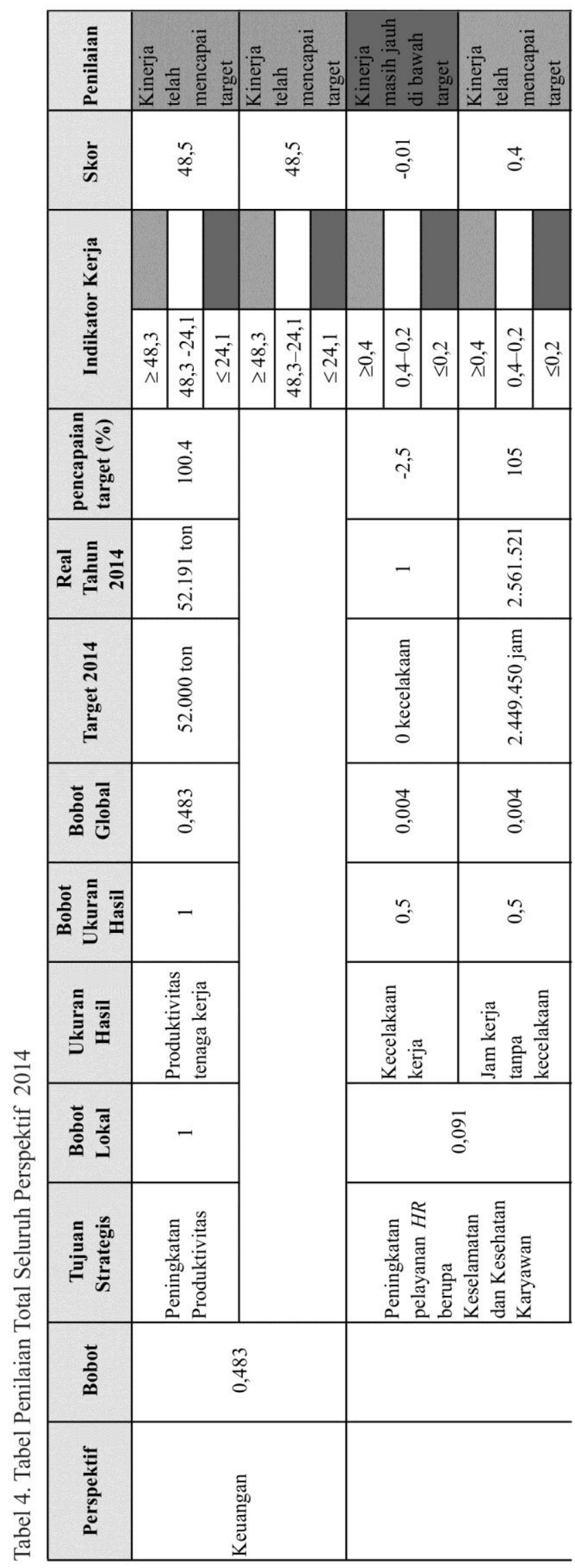




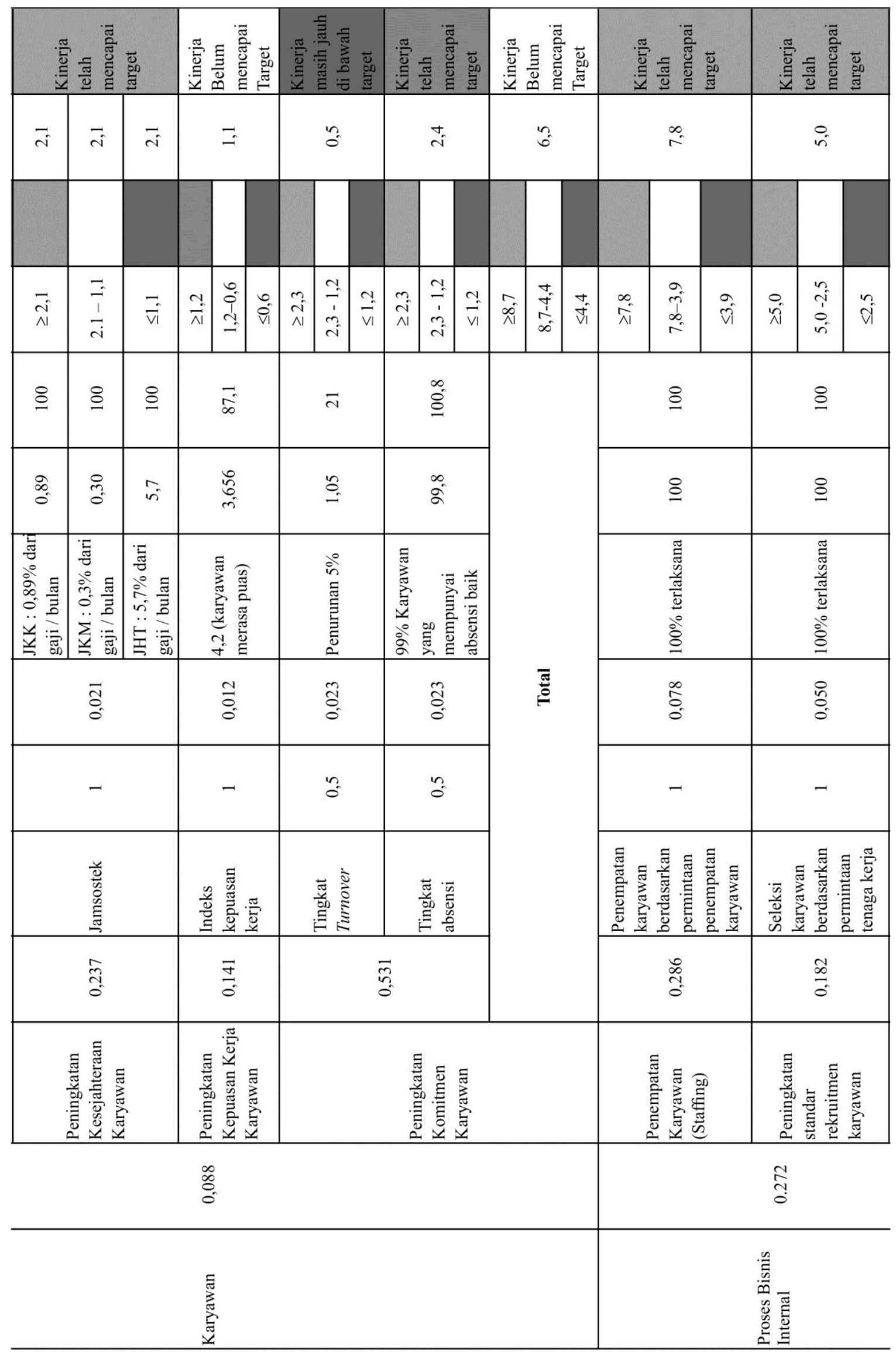




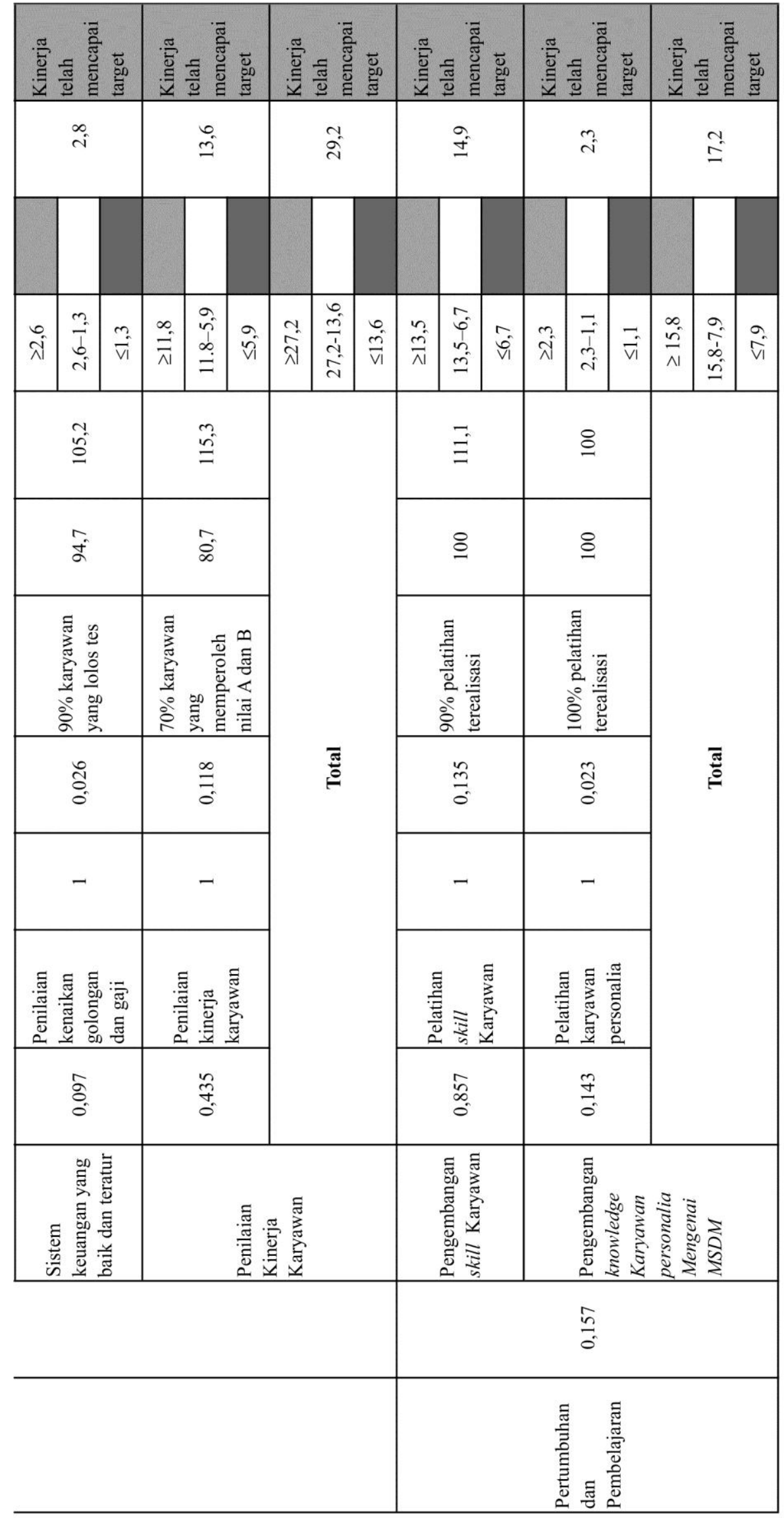

